\title{
School Matters
}





\section{School Matters}

Peter Mortimore, Pamela Sammons, Louise Stoll, David Lewis and Russell Ecob 
First published in 1988 by the University of California Press

(C) Peter Mortimore, Pamela Sammons, Louise Stoll, David Lewis and Russell Ecob 1988

All rights reserved. No part of this publication may be reproduced or transmitted in any form or by any means, electronic or mechanical, including photocopy, recording, or any information storage and retrieval system, without permission in writing from the publisher.

Library of Congress Cataloging-in-Publication Data

School matters.

Bibliography: $\mathrm{p}$.

Includes index.

1. Education, Elementary - England - London -

Evaluation - Longitudinal studies. I. Mortimore,

Peter.

LA633.S35 $1988 \quad 372.9421^{\prime} 2 \quad 88-17299$

ISBN 0-520-06502-6

ISBN 0-520-06503-4 (pbk.)

Typeset by Character Graphics, Taunton

Printed and bound in Great Britain by

A. Wheaton \& Co Ltd, Exeter 